\title{
The Unique Folding Style in the Zagros Simply Folded Belt, the Kuh-e Qazi Anticline, South Iran
}

\author{
Zahra Maleki \\ Department of Geology, Science and Research Branch, Islamic Azad University, Tehran, Iran \\ Email: z.maleki@srbiau.ac.ir
}

Received 21 April 2015; accepted 28 July 2015; published 31 July 2015

Copyright (C) 2015 by author and Scientific Research Publishing Inc. This work is licensed under the Creative Commons Attribution International License (CC BY). http://creativecommons.org/licenses/by/4.0/ (c) (i) Open Access

\section{Abstract}

The study area is located in the Zagros Simply Folded Belt of Iran and in the interior Fars sub-basin (175 km from Persian Gulf). The Zagros fold-thrust belt is home to one of the largest petroleum producing reservoirs in the world. Structures in this area have complications and the study anticline has unique structures in the Fars region. In the study area, the Kuh-e Qazi anticline due to special fold style and rotation toward Northeast is the unique structure between anticlines of the Zagros belt. This anticline is fault bend fold and plunge of the anticline in eastern part rotated toward Northeast along with the Nezamabad fault trend. In this area, the Kuh-e Qazi anticline has asymmetric structures and some faults such as the Nezamabad and the Sarvestan strike slip fault effect on this anticline. The geometry of anticlines in the Zagros fold-thrust belt is affected by the type of deformation and mechanical behavior of stratigraphic units specially detachment units. The purpose of this research is to determine of folding pattern of the Kuh-e Qazi anticline and define structural features affected on them in the study area. This paper presents a part of the results of a regional study of the Fars province in the Zagros Simply Folded Belt, based on original fieldwork, satellite images, structural sections, geological maps and well data. Also, we use some software as Global Mapper and Tectonics FP for preparing some data. Based on the research, which have been done, the boundary between ductile and frictional substrates causes rotation as a result of lateral, along-strike migration of the ductile substrate. The ductile or viscose layer in the study area is Hormuz Series. Due to lack or thinning of Hormuz salt over the Gavbandi basement high and in the eastern side of the Nezamabad basement fault, causes translation of strain and anticlockwise rotation in Southeast of the Kuh-e Qazi anticline toward Northwest unlike foreland basin due to the Nezamabad fault activity. This style between all of the anticlines in the study area is unique that rotates unlike foreland basin. In addition, influence on anticlockwise rotation, extensional stress has been created and then salt dome cropping out in Southeast of the Kuh-Qazi anticline. One of the best evidence for effect of extensional stress is triangular facets in this part of the study anticline. Based on folding analysis (geometry of axial plane and fold orien- 
tation), it is clearly confirmed that the translation of strain and anticlockwise rotation in Southeast of the Kuh-e Qazi anticline toward Northwest has been formed by basement fault activity as the Nezamabad fault in the boundary between ductile and frictional substrates of the study area.

\title{
Keywords
}

\author{
Zagros, Iran, Kuh-e Qazi Anticline, Rotation, Fold Style, Nezamabad Fault
}

\section{Introduction}

The Study area is located in the Zagros Simply Folded Belt of Iran and in the interior Fars sub-basin [1] [2] (Figure 1). The Zagros fold-thrust belt is home to one of the largest petroleum producing reservoirs in the world [3]. This belt is recognized by the NW-SE trending parallel anticlines that verge to the SW in a $6-12 \mathrm{~km}$ cover sequence [3] [4]. Based on Physiographic-tectonic zoning map of Iran's (sedimentary basins of Iran), the study area is located in the Zagros-East Taurus hinterland [5]. The Simply Folded Zone (SFZ) is an orientation as southwesterly boundary of the Zagros orogen near the Persian Gulf. In this region, the folds are capped by the Oligocene Asmari Limestone [3] [6] [7] and the sedimentary cover sequence is floored by the Hormuz Formation, a dominantly evaporate formation, which acts as a major decollement horizon [8]-[10].

In the Zagros fold-thrust belt, the Kuh-e Qazi anticline has asymmetric structures (Figure 2). This structure is located in the Fasa area of the Fars province (170 km from Persian Gulf). Structures in this area have complications and the study area has unique structure in the Fars region. The geometry of anticlines in the Zagros foldthrust belt is affected by the type of deformation and mechanical behavior of stratigraphic units specially detachment units [11]. In this belt, detachment units are important for controlled folding pattern [12] [13]. The basal Hormuz and other detachments play important roles in the style of the Zagros fold-thrust belt structures. One of the main detachment units in the study area is Dashtak formation that belongs to Kazeron group. This formation is composed of evaporate, shale and dolomite units. This formation has an important role in folding geometry especially in the Fars region. In addition, other detachment formations in this area are Kazdomi and Gachsaran formations that play important roles in the structural style of area.

In the Zagros fold-thrust belt, structural analysis of surface and subsurface data shows that salt layers such as Cambrian Hormuz and the Miocene Gasharan have the direct control on the structural style [11]. Until now, in the Zagros fold-thrust belt, many studies have done in variation of structural style and effects of detachment folding on folding pattern [12] [13]. Also, many researchers discuss basement involvements and reactivated structures in the Zagros fold-thrust belt and its roll on folding pattern, e.g. [10] [14]-[18]. Several researchers, such as Kashfi (1972), Falkon (1969), Alavi (1994), Letouzey (2005) and Sherkati et al. (2005), emphasized the role of mechanical stratigraphy on the structural style as in above-mentioned.

For the first time, Stearns (1978) introduced the concept of mechanical lithology in this area and O’Brien (1950) [19] was the first one to show the effects of detachment layers on folding process and other researchers have discussed about this too, e.g. [11] [12] [20]-[23].

The first geological report on the Kuh-e Qazi anticline dated back to the 1974 by the National Iranian Oil Company (NIOC) and SOFIRAN EGOCO (Exploration Company). Some researchers just briefly studied on this region and introduced the Kuh-e Qazi anticline as an affected fold by the Nezamabad and the Sarvestan strike slip fault zone [23] [24].

Description of fold geometry is important because they allow comparisons within and between folds and pattern-recognition in addition to occurrence and distribution of fold systems. The main aim of this paper is to determine of folding pattern of the Kuh-e Qazi anticline and define structural features affected on them in the study area.

\section{Material and Methods}

This paper presents part of the results of a regional study of the Fars province in the Zagros Simply Folded Belt, based on original fieldwork, satellite images, structural sections, geological maps and well data. Our fieldwork in the study area and some data such as geological maps and geological regional data were prepared and provided 


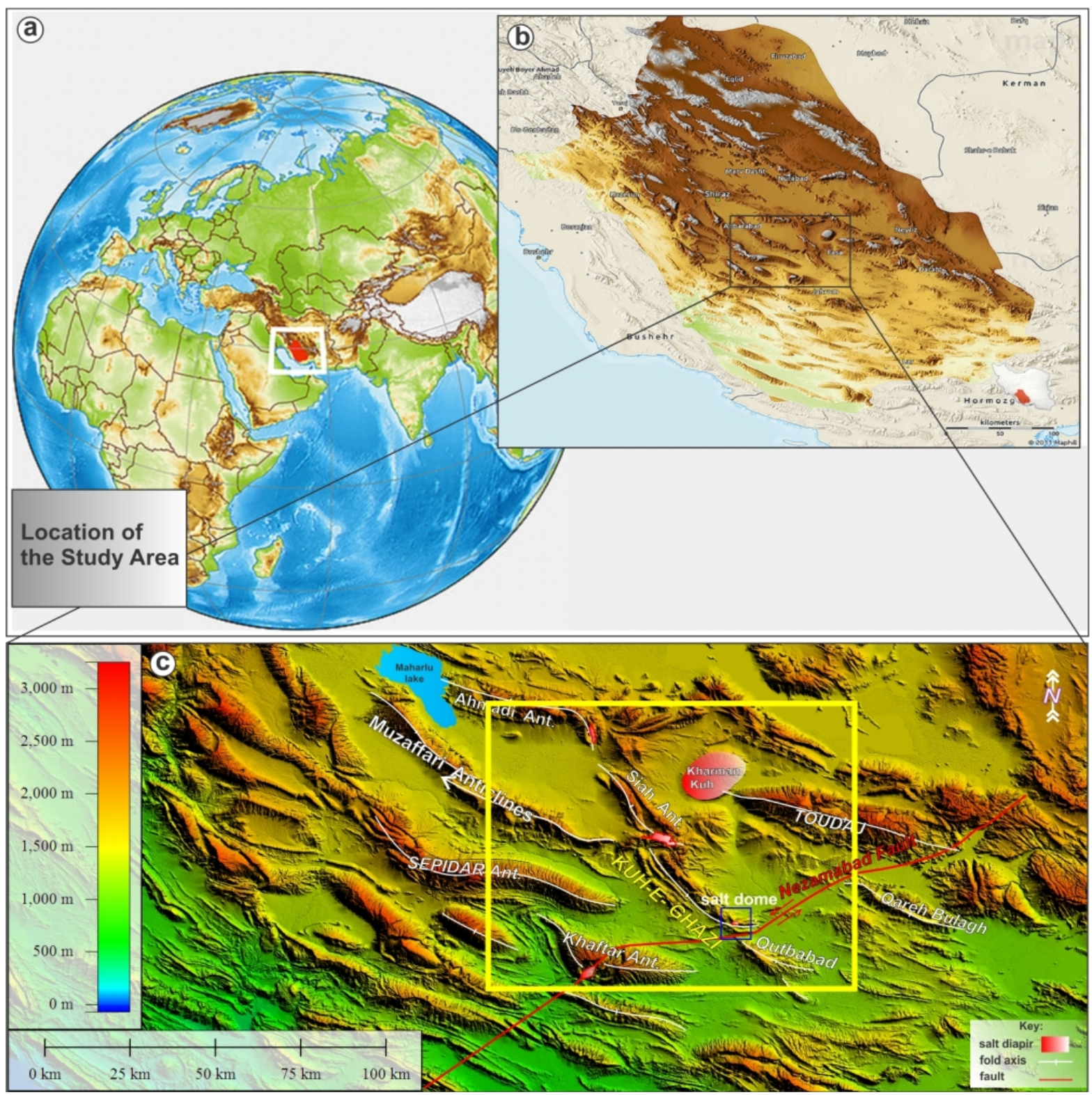

Figure 1. Landsat Satellite image shows the study area and location of the Kuh-e Qazi anticline in the Zagros fold-thrust belt, South of Iran. Inset Satellite image (a) shows location of the study area with white framework in the Middle East. In addition, in this figure shows location of the Kuh-e Qaziand its salt plug in the blue square.

by the National Iranian Oil Company (NIOC). In the study area, not provided seismic data to analysis and discuss the structural features by oil companies in this region. All geological reports have studied and all the elements of fold style have calculated and analyzed. We used fold style elements analysis methods (description of folds) based on [25]-[29]. We used Tectonics FP software for prepared and analyzed Stereoplots of the Kuh-e Qazi anticline. Also, we used Global Mapper Software for prepared 3D Path Profile (along cross sections). The Profiles (3D Path) prepared based on Digital Elevation Model (DEM) and geological map of study area (published by the National Oil Company and the Geological Survey of Iran).

\section{Geological Setting and Stratigraphy}

In this paper, the study area is located in the Zagros orogenic belt. The Zagros fold and thrust belt was formed by collision of two tectonic plates the Eurasian or Iranian and Arabian plates. In this belt, the Fars region, based 


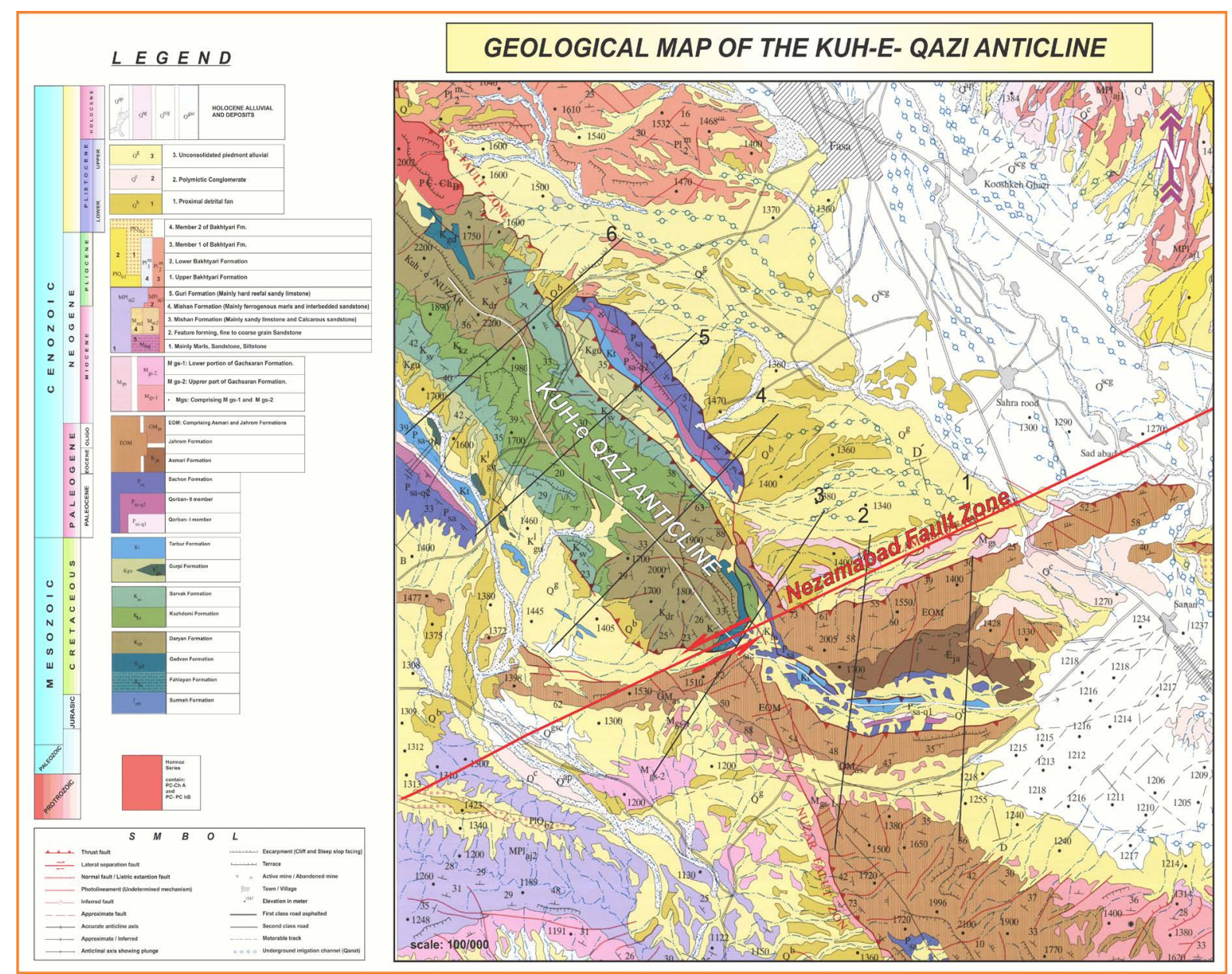

Figure 2. Geological map of the Kuh-e Qazi anticline. In this map shows the location of the Nezamabad fault zone in this area. Modified after [37].

on geological fancies units perpendicular to Zagros belt was divided into the interior Fars, coastal Fars and sub-coastal Fars sub-basins [1] [2] and the study area is located in the Interior Fars sub-basin. This area is easily recognized by the NW-SE orientation parallel anticlines that verge to the SW in a 6 - $12 \mathrm{~km}$ cover sequence [3] [26] [30]-[34].

In the Zagros fold-trust belt, the oldest known stratigraphic unit with 2000 - 1000 meters thickness estimated as Hormuz Series [32] [33] and is exposing in the form of salt domes in the Fars region. Structures in this area have complications and the oldest stratigraphy unit that outcropped in the Kuh-e Qazi anticline on the surface belongs to Hormuz Series (salt plug). The age of Hormuz Series is Pre-Cambrian-Cambrian.

Anticlines outcropping stratigraphic units in the most of structures Fars region often include Upper Cretaceous stratigraphic units (MaesTryshtyn-Campanian to the present) and in the sub-coastal Fars region, includes the Lower Cretaceous stratigraphic units (Neocomian to the present). The Kuh-e Qazi anticline is a well-developed anticline in which the uppermost Ilam and Gurpi formations are exposed. Also, in the interior Fars sub-basin, the oldest outcrops is Hormuz Series observed in the Kuh-e Khaftar, the Kuh-e Qazi and the Surmeh anticlines with form of salt domes [1] [2] [34].

The Kuh-e Qazi anticline is located in the Fassa area of the Fars province (170 km to Persian Gulf). This anticline has three orientations that consist of North-Northwest and South-Southeast. This anticline is bounded from North by the Siah anticline, from West-Southwest by the Khaftar and the Sepidar anticline and from East by the Qutbabad anticline (Figure 1).

The Kuh-e Qazi anticline is an asymmetric structure, which has $60 \mathrm{~km}$ length and 8 - $12 \mathrm{~km}$ width (Figure 2). Based on Setchell et al. (2007), the Kuh-e Qazi anticline is a fault bend fold and in Southeastern of the Kuh-e 
Qazi anticline, cropping out a small salt plug (Figure 1).

\section{Structural Style of the Kuh-e Qazi Anticline}

In the Zagros Simply Folded Belt, Fars region (Fassa area), the Kuh-e Qazi anticlinedue to special fold style and rotation toward Northeast is unique structure between anticlines of the Zagros belt. This anticline is located 170 $\mathrm{km}$ distance from Persian Gulf (Figure 1). Structures in this area have complications and the oldest stratigraphy unit that outcropped in the Kuh-e Qazi anticline on the surface belongs to Hormuz Series (small salt plug) inSoutheastern part of the anticline. Age of the oldest rock unit is Pre-Cambrian-Cambrian.

As mentioned the Kuh-e Qazi anticline has unique structure between anticlines in the Zagros fold-thrust belt. In the Zagros fold-thrust belt, anticlines have vergence toward the Zagros foreland basin (Southwest), but the Kuh-e Qazi anticline unlike the other anticlines in the study area has vergence to Northeast.

Some faults have caused main deformation such as rotation of fold axis, formation salt domes and changes on the structural style of anticline in the study area. Main faults in the study area are the Nezamabad fault and the Sarvestan fault that introduced as basement fault by [35] [36]. The Nezamabad fault is sinistral strike slip fault and the Sarvestan fault is dextral strike slip fault that these faults affected on the structures in the Fars area [34] [37]. These case same as the Kuh-e Qazi anticline in the Fars area. In the study area, this anticline is asymmetric fold with rotation axis affected by activity of the Nezamabad (Figure 1, Figure 2) fault. May be the Sarvestan fault caused some changes on the Kuh-e Qazi anticline.

Based on Oliver (1987) [38], the folds in the cover on each side of the basement fault tend to be asymmetric, and in the upper levels of the cover verge towards the line of the basement fault. In addition, Oliver noted that the sense of asymmetry of a fold would change as it passes over the basement fault. Thus, as can be seen from Figure 3, Figure 4 the sense of asymmetry of the Kuh-e Qazi anticline would change as it passes over the Nezamabad basement fault.
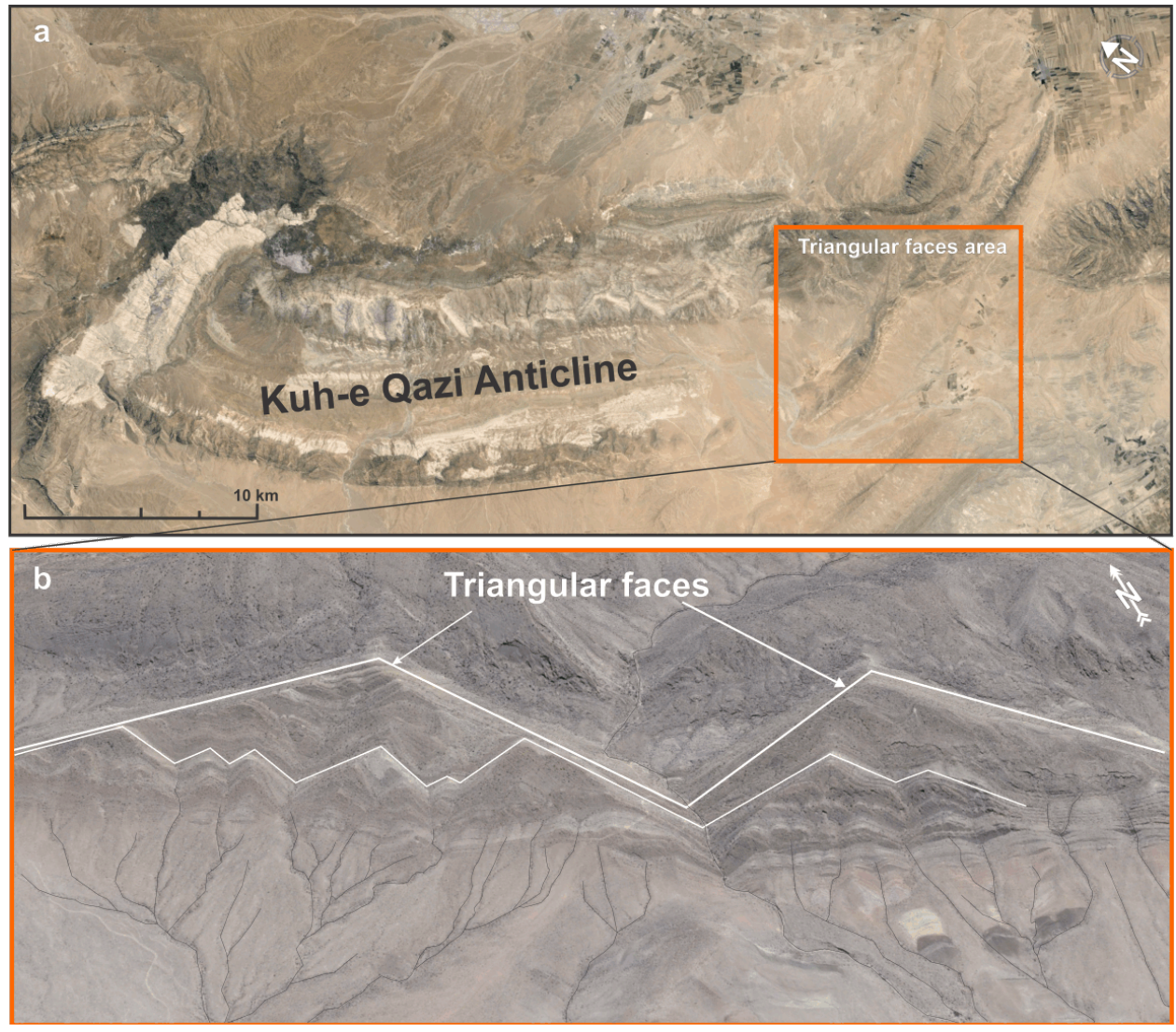

Figure 3. Triangular facets in Southwestern limb (east part of the study area) provide evidence for recent normal fault movement and extensional stress. 


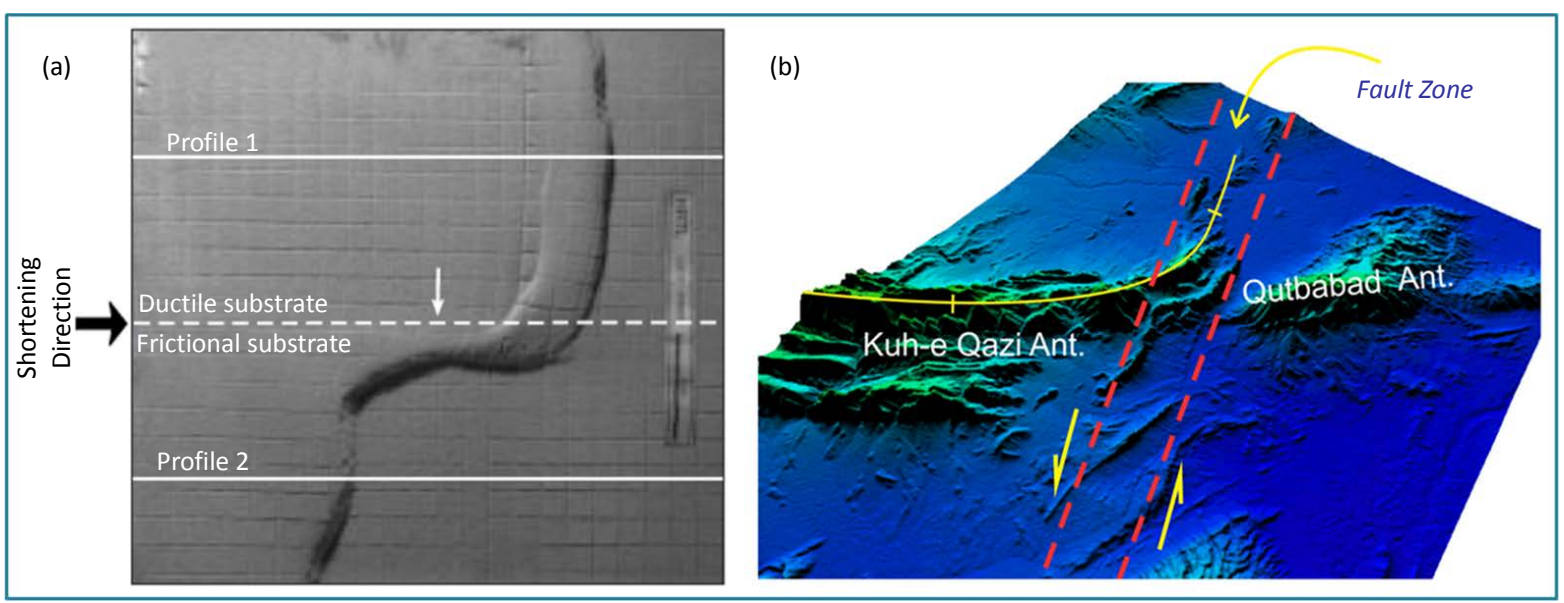

Figure 4. (a) The boundary between ductile and frictional substrates caused rotation as a result of lateral, along-strike migration of the ductile substrate (Cotton and Koyi, 2000) [39]. (b) This figure shows the anticlockwise rotation in the Kuh-e Qazi anticline. This rotation has created toward Northwest unlike foreland basin in the Nezamabad fault zone.

Some researchers [36]-[38] believed that the Nezamabad strike slip is a basement fault with NE-SW trend in the Zagros fold-thrust belt that affected on the structures in the Fars region. In the study area, this fault effect on East-Northeast parts of the Kuh-e Qazi anticline with rotation to Northeast. This change as it passes over the Nezamabad fault with activity basement fault. As mentioned in the introduction part, the oldest known stratigraphic unit in the Fars area, as Hormuz Series [32] [33]. However, thickness of Hormuz Series is different in this area, with 2000 - 1000 meters thickness estimated and is exposing in the form of salt domes in the Fars region. For example in the study area, the Nezamabad basement fault limited the Gavbandi basement high from Central Zagros.

Neoproterozoic Hormuz salt is the basal detachment level through the study area. However, due to lack or thinning of Hormuz salt over the Gavbandi basement high and in the eastern side of the Nezamabad basement fault, its efficiency decreased as an basal detachment and resulted in activity of other potential intermediate detachment horizons in stratigraphic column (such as Triassic evaporates and shales, Dashtak formation) during folding. Because of lack or thinning of Hormuz salt over the Gavbandi basement high and in the eastern side of the Nezamabad basement fault, salt domes are not cropping out in this area. In spite of salt domes are not cropping out in this area, one small salt dome is cropping out in Southeastern of the Kuh-Qazi anticline. Because of this anticline in this part has anticlockwise rotation, it seems that cropping out salt dome in this area. In addition, influence on anticlockwise rotation, extensional stress has created and then salt dome cropping out in Southeast of the Kuh-Qazi anticline. One of the best evidence for effect of extensional stress is triangular facets in this part. In the most typical usage of this term, triangular facets (or faceted spurs) have formed by active faulting, especially normal faulting that produces well-defined triangular facets along a mountain. These triangular facets provide evidence for recent normal fault movement [40]-[42]. In Figure 3, you see triangular facets in Southwestern limb (east part of the study area) provide evidence for recent normal fault movement caused by anticlockwise rotation and extensional stress.

Based on Cotton and Koyi (2000) [43] experimental modelling (Figure 4(a)), the boundary between ductile and frictional substrates caused rotation as a result of lateral, along-strike migration of the ductile substrate. The ductile or viscose layer in the study area is Hormuz Series. As mentioned lack or thinning of Hormuz salt over the Gavbandi basement high and in the eastern side of the Nezamabad basement fault, caused translation of strain and anticlockwise rotation in Southeastern of the Kuh-e Qazi anticlinetoward Northwest (Figure 4(b)) unlike foreland basin. This style between all of the anticlines in the study area is unique that rotate unlike foreland basin.

\section{The Description of Folds}

Description of fold geometry is important because they allow comparisons within and between folds and allow us to recognize patterns in the occurrence and distribution of fold systems. For example, orogenic belts contain 
characteristic fold systems: along their flanks are large fold and thrust belts, with little metamorphism, but underlain by decollement; and in core zones where intense folding has accomplished, accompanied by high-grade metamorphism under high temperature and pressure.

\section{Elements of Fold Style}

The style of a fold is the set of characteristic that describe its form. Over years of working with folds, geologists have identified certain features as particularly useful in describing fold and understanding how they develop [28]. Based on results of elements of fold style analysis can be analyzed deformation in the study area [44]-[46].

Because the Kuh-e Qazi anticline, has unique structure; the analysis of fold style elements is seems necessary. Therefore, for more studies on this structure the changes of fold style elements have analyzed and investigated from east to west in the different parts of this anticline. Because of the Nezamabad fault effect on the middle parts of the Kuh-e Qazi anticline, we have evaluated and calculated some elements of fold style, measurable in this structure. In this respect, symmetry, cylindricity, geometry of axial plane and fold orientation have evaluated and analyzed.

\subsection{Symmetry}

A folded surface forms a symmetric fold if in profile, the shape on one side of the hinge is a mirror image of the shape on the other side, and if adjacent limbs are identifiable in length [26]. The study anticline is an asymmetric fold with changed plunge in North of the Western part of fold. The Kuh-e Qazi anticline is an asymmetric anticline. In Southern flank, dip of layers is greater than Northern flank on the Asmari formation horizon (Figure 5 and Figure 6). In Southern flank, layers have dip changes from about $65^{\circ}$ to $75^{\circ}$ and dip value in Northern flank

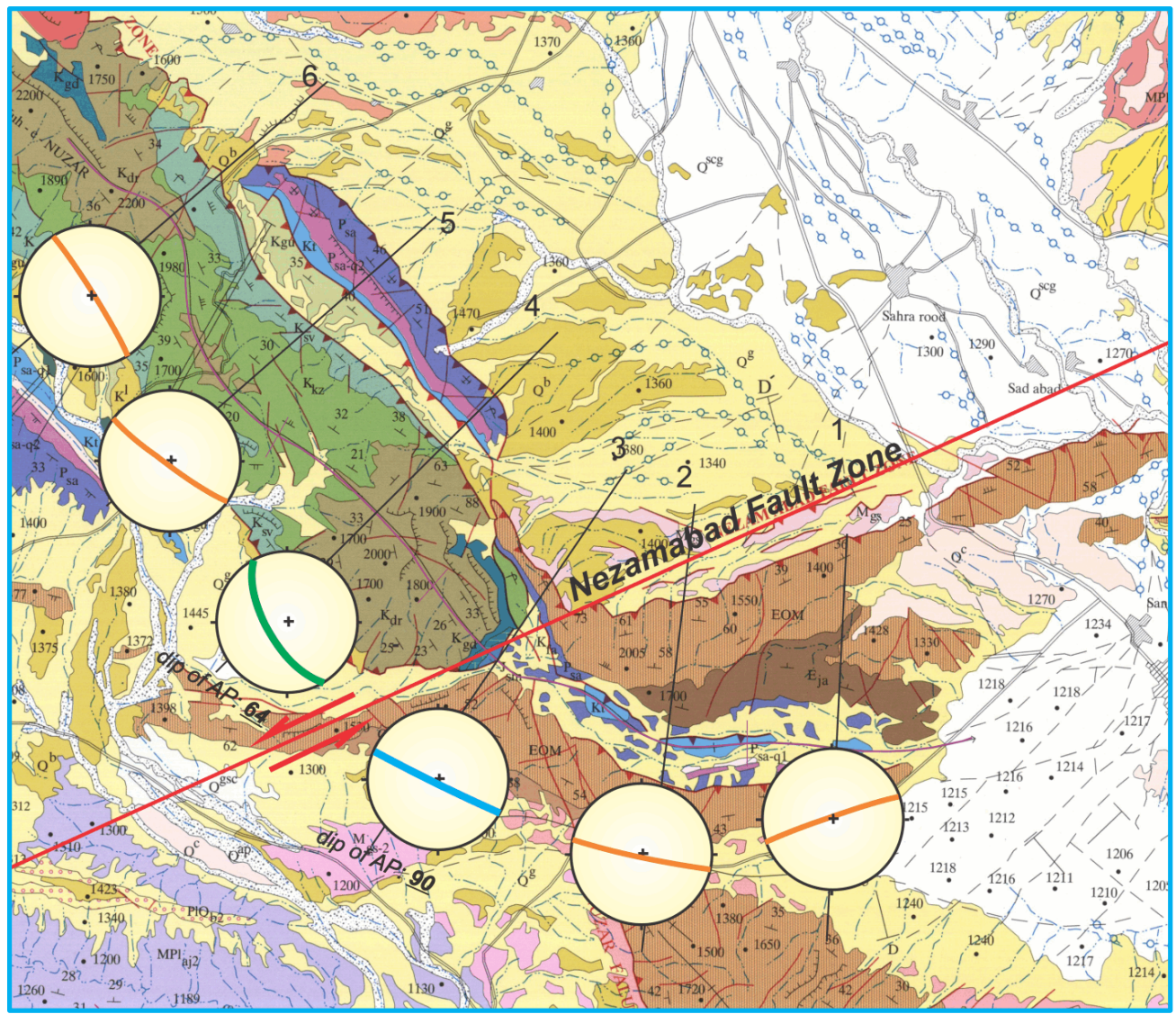

Figure 5. This figure shows the location of axial planes of Kuh-e Qazi anticline based on Twiss and Moors method (1992) for description of fold and gave results of stereoplots in this anticline, map scale 1:100,000 [37]. 


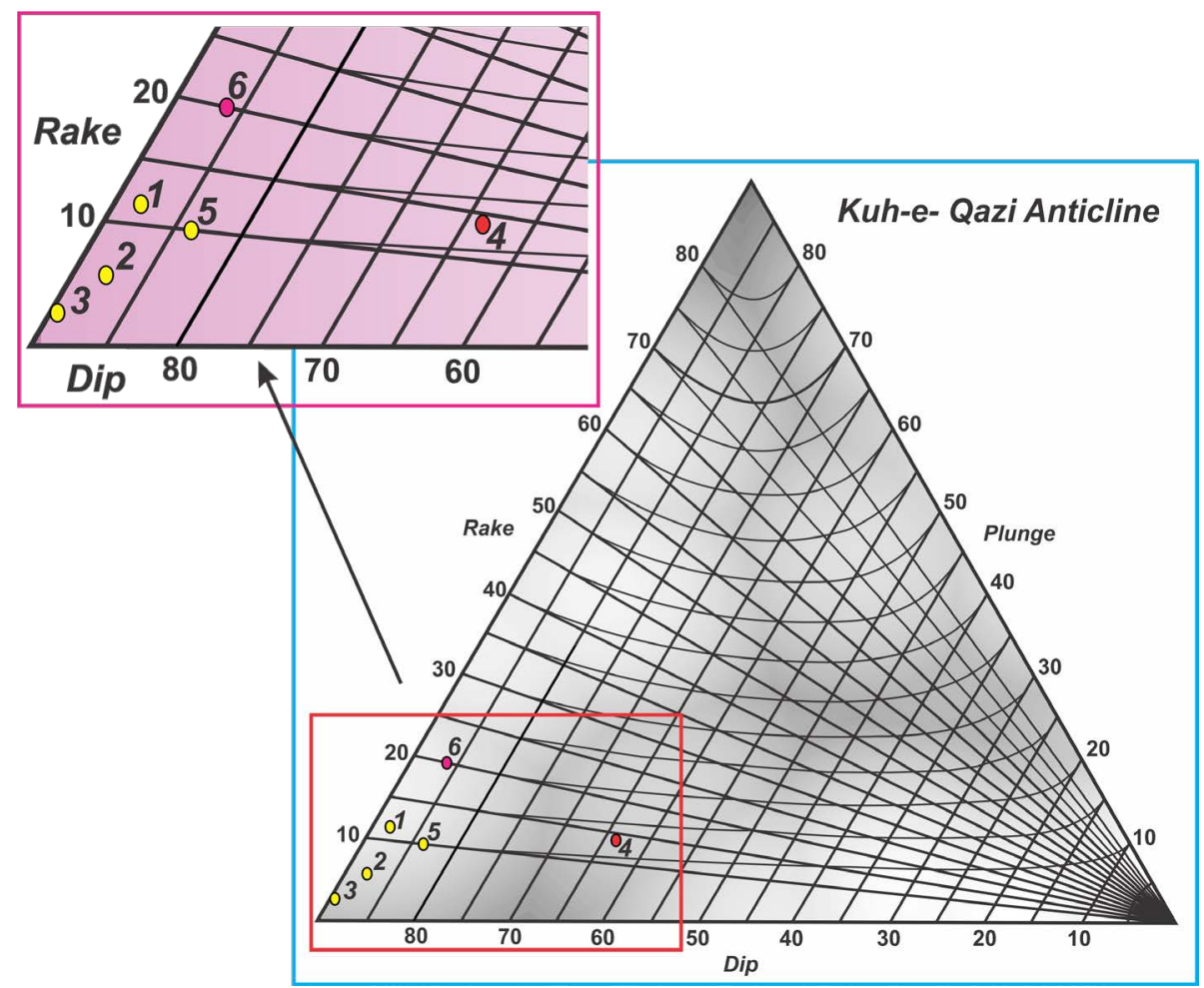

Figure 6. Triangle form Diagram shows type of fold in six sections of the Kuh-e Qazi anticline, based on [29].

ranges about $50^{\circ}$ to $70^{\circ}$. In eastern part of the Kuh-e Qazi anticline, Southern limb has more than dip to northern limb into Western part.

\subsection{Cylindricity}

The cylindricity is represented qualitatively on a stereonet by how closely the poles to planes around a fold fit a great circle distribution [26]. The studied anticline is a cylindrical to conical fold with changed plunge in the North of Western part of fold. The output of Tectonics FP software for six parts of the Kuh-e Qazi anticline is show in the Figure 7.

\section{Classification of the Fold}

\section{Based on Geometry of Axial Plane and Fold Orientation}

Based on Twiss and Moors method (1992) for description of fold, six stereoplots (output of Tectonics FP software) were prepared for six parts of the Kuh-e Qazi anticline. According to results, these stereoplots show the location of axial plane (AP) and cylindricity (AC) and plunge of fold (P) (Figure 7). This part prepared based on six structural cross sections of the Kuh-e Qazi anticline. The locations of these structural cross sections (from No. 1 to No. 6) are show in the Figure 2 and Figure 3. Also in Figure 8, profiles of the Kuh-Qazi anticline is show (location of these profiles is matched along the cross sections No. 1 to No. 6 in the study area.

According to description of fold [26] for six sections in the Kuh-e Qazi anticline (from No. 1 to No. 6, Figure 9), the geometry of axial plane is planer. In the six structural cross sections of the Kuh-e Qazi anticline, dip value of axial plane is changing from $64^{\circ}$ to $90^{\circ}$. Based on classification of Ramsay (1967) [27] for fold classification and changes of axial plane in different parts of the anticline, the fold type in the No. 3 and No. 4 sectionshave main different to other parts (Figure 5, Figure 7). These changes specially are seen in the part of the Kuh-e Qazi anticline that math to No. 4 structural section. Based on Figure 6 for classification of axial plane in the study anticline, type of the axial plane of the No. 4 section is steeply inclined-sub horizontal. As mentioned before in part 4 of this paper, the study anticline affected by basement fault and ductile-friction deformation has been anticlockwise 


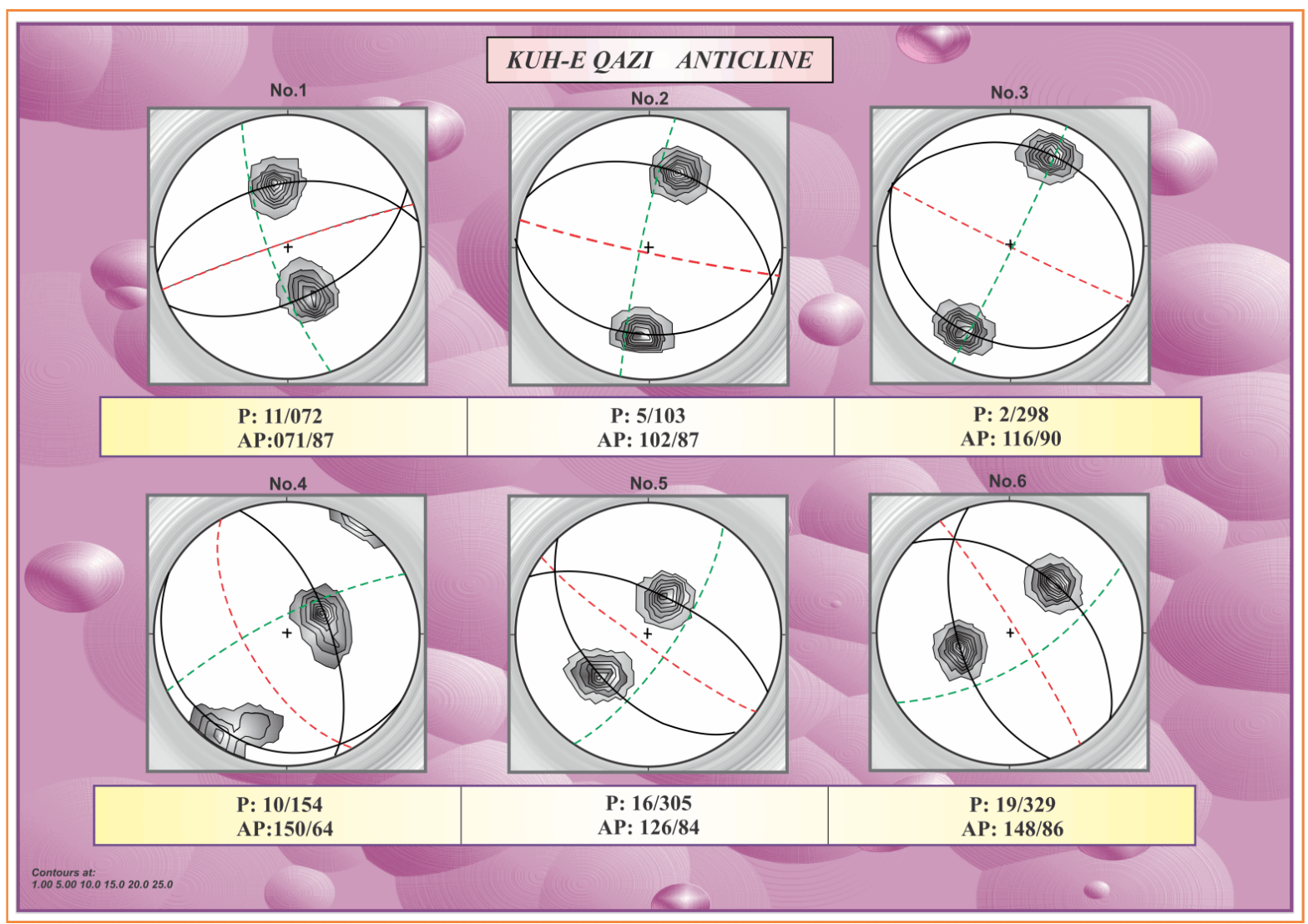

Figure 7. Stereoplots show the axial planes (AP), cylindricity (AC) and plunge of fold (P) for six sections of the Kuh-e Qazi anticline (based on classification [26]).

rotation. It seems that as compared to other parts, fold style in No. 1 and No. 4 sections have been affected more deformation effect of anticlockwise rotation of the Kuh-e Qazianticline. Also main change from dip of axial plane and location of them (Figure 5), as well as indicate effect of rotation in No. 2, No. 3 and No. 4 sections, relative to each other structural parts of the Kuh-e Qazi anticline. These evidence shows, as well as basement fault effects from anticlockwise rotation affected by basement fault in this area.

Based on Rickard (1971) [29] and Ramsay (1967) [28] for fold orientation classification. The orientation of a cylindrical fold is completely defined by the attitude of the hinge and hinge plane together with a statement of the direction in which the limbs converge at the hinge or closure [38]. The value of graphical schemes in Figure 6 is suitable for analyzing and displaying the orientation of folds lies in their comprehensiveness.

In structural section No. 2 and No. 3 type of fold is Upright, Sub-horizontal. In structural section No. 1, No. 5 and No. 6 type of fold is upright-gently plunging. The similarity of type fold in these sections is indicated formation of fold in these parts has been affect same stress and strain. In structural section No. 4 type of fold is steeply inclined, sub-horizontal and as well as shown main change affect by anticlockwise rotation of vergence of the Kuh-e Qazi anticline. According to classification of Rickard (1971) [29] and Ramsay (1967) [28] (Figure 6, Figure 9 and Figure 10) actually can be seen changes of structural style and fold style changes in the study anticline.

\section{Conclusions}

In the Zagros Simply Folded Belt, Fars region (Fassa area), the Kuh-e Qazi anticline due to special fold style and rotation toward Northeast is a unique structure between anticlines of the Zagros belt. Based on the research, which have been done, the boundary between ductile and frictional substrates causes a rotation as a result of lateral, along-strike migration of the ductile substrate. The ductile or viscose layer in the study area is Hormuz Series. As mentioned lack or thinning of Hormuz salt over the Gavbandi basement high and in the eastern side of the 


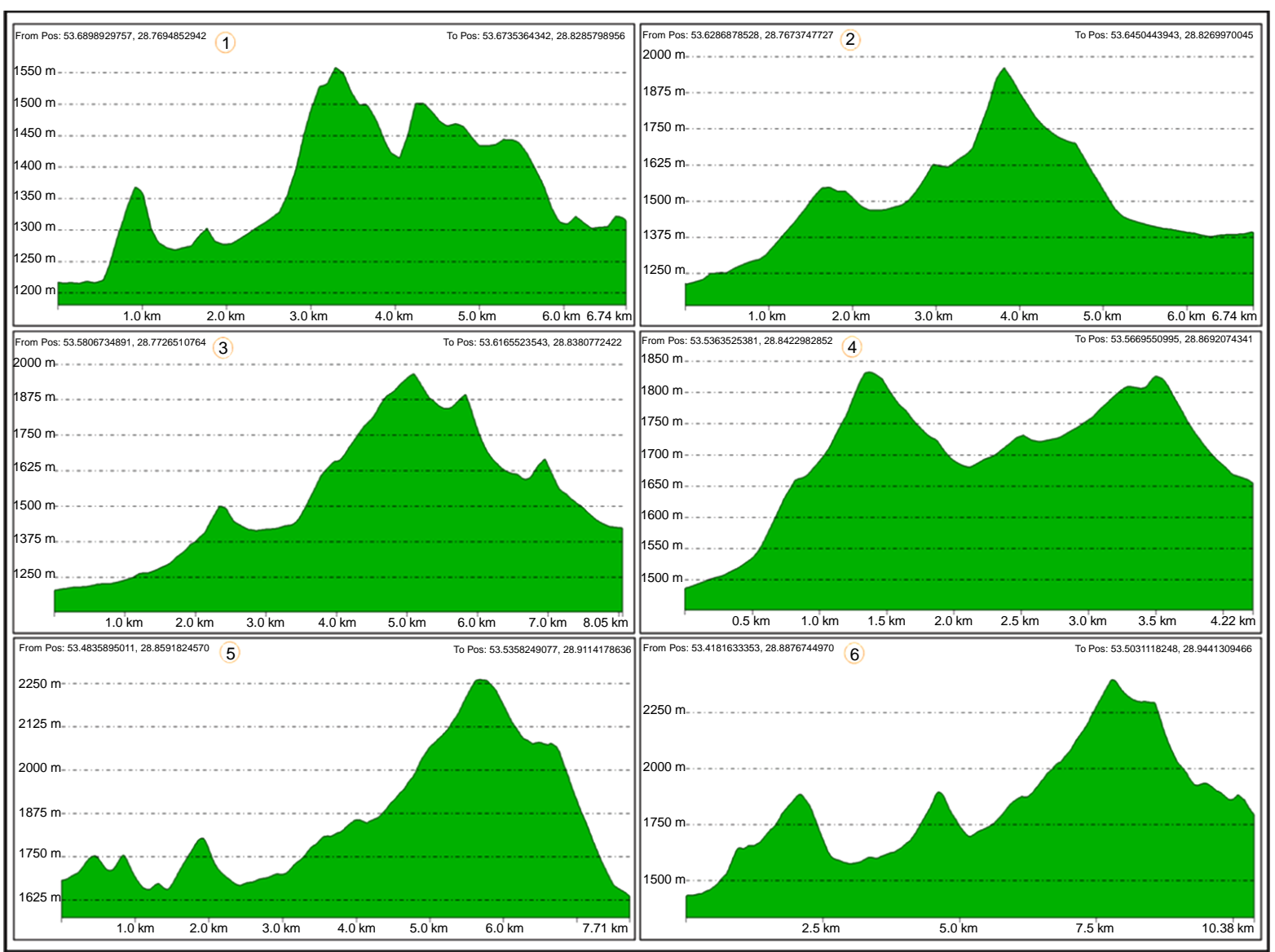

Figure 8. The profiles of the Kuh-e Qazi anticline show that location of these profiles that is match along the cross sections No. 1 to No. 6 in the study area.

Nezamabad basement fault, causes a translation of strain and anticlockwise rotation in Southeast of the Kuh-e Qazi anticline toward Northwest unlike foreland basin. This style between all of the anticlines in the study area is unique that rotates unlike foreland basin. In addition, influence on anticlockwise rotation, extensional stress has been created and then salt dome has been cropped out in Southeast of the Kuh-Qazi anticline. One of the best evidence for the effect of extensional stress is triangular facets in this part of the study anticline. Based on folding analysis (geometry of axial plane and fold orientation), it is clearly confirmed that the translation of strain and anticlockwise rotation in Southeast of the Kuh-e Qazi anticline toward Northwest has been formed by basement fault activity in the boundary between ductile and frictional substrates of the study area.

Based on fold style analysis, structural sections No. 2 and No. 3 type of fold are upright and sub-horizontal. Structural sections No. 1, No. 5 and No. 6 type of fold is upright-gently plunging. The similarity of type fold in these sections is indicated formation of fold in these parts that has been affected same stress and strain. Structural section No. 4 type of fold is steeply inclined, sub-horizontal and as well as shown the main change affect by anticlockwise rotation of vergence of the Kuh-e Qazi anticline. According to classification of fold style, actually the changes could be seen in structural style and fold style of the study anticline.

It seems that as compared with other parts, fold style in No. 1 and No. 4 sections has affected more deformation effects of anticlockwise rotation of the Kuh-e Qazi anticline. Also the main change from dip of axial plane and location of them, as well as indicate the effect of rotation in No. 2, No. 3 and No. 4 sections, which are relative to each other structural parts of the Kuh-e Qazi anticline. These evidence shows, as well as basement fault effects from anticlockwise rotation affected by basement fault in this area. Due to lack or thinning of Hormuz salt over the Gavbandi basement high and in the eastern side of the Nezamabad basement fault, causes translation of strain and anticlockwise rotation in Southeast of the Kuh-e Qazi anticline toward Northwest unlike foreland basin due to the Nezamabad fault activity. 


\begin{tabular}{|c|c|c|c|c|c|}
\hline No. 1 & No. 2 & No.3 & No. 4 & No. 5 & No. 6 \\
\hline 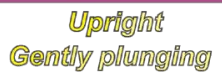 & $\begin{array}{c}\text { Upright } \\
\text { Sub-horizontal }\end{array}$ & $\begin{array}{c}\text { Upright } \\
\text { Sub-horizontal }\end{array}$ & $\begin{array}{l}\text { Steeply inclined } \\
\text { Sulbu horftzontal }\end{array}$ & $\begin{array}{c}\text { Upright } \\
\text { Gently plunging }\end{array}$ & $\begin{array}{c}\text { Upright } \\
\text { Gently plunging }\end{array}$ \\
\hline
\end{tabular}

Figure 9. This figure shows type of fold in six sections of the Kuh-e Qazi anticline. This classification based on [27] [29].

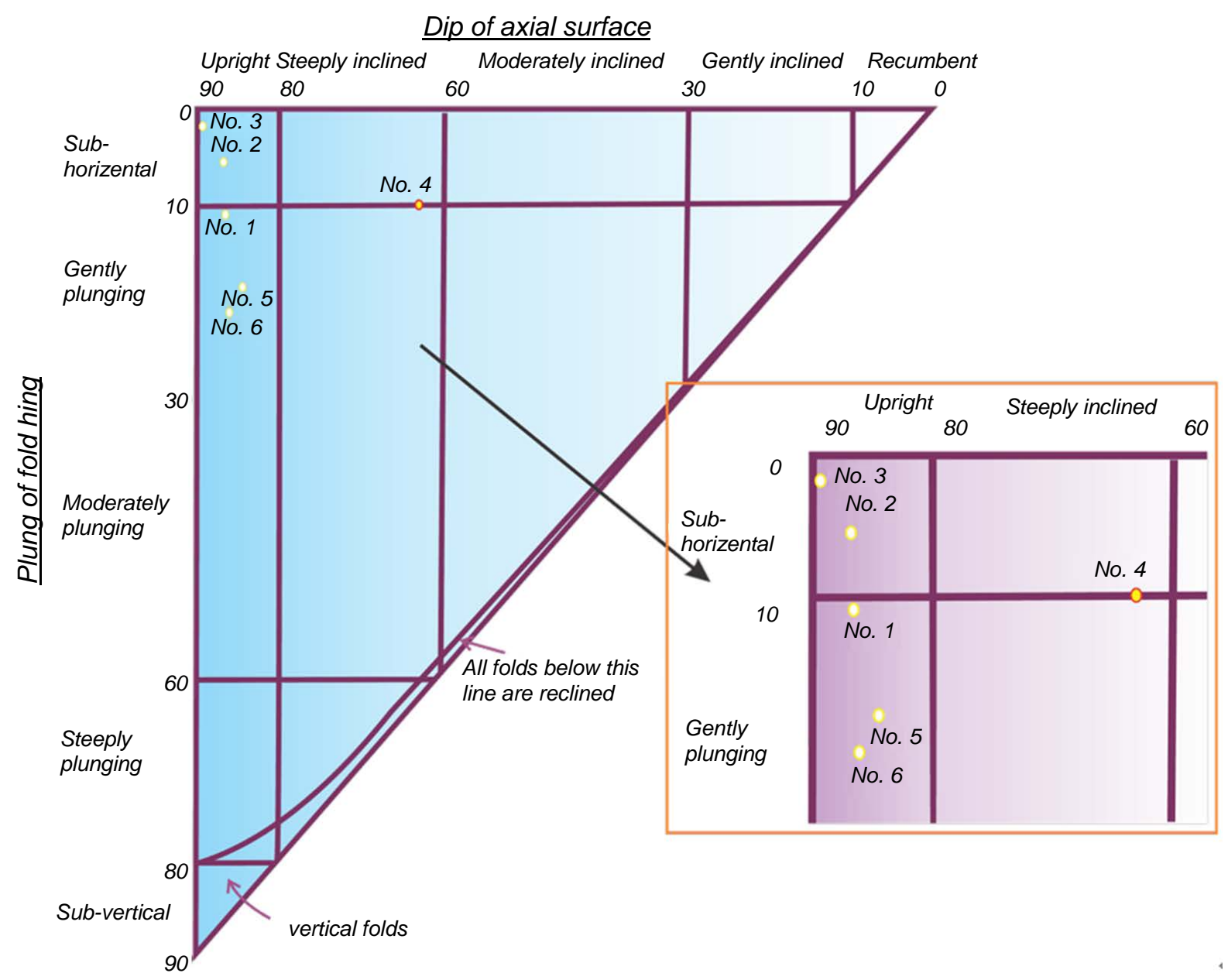

Figure 10. This figure shows the classification for orientation of the Kuh-e Qazi anticline based on [42].

\section{Acknowledgements}

The author acknowledges the Department of Geology, Islamic Azad University, Science and Research Branch, Tehran, Iran for funding this project and gratefully acknowledges Dr. M. Arian, Dr. A. Solgi, Dr. M.A. Ganjavianand, Dr. N. Dehbashi Ghanavati for their guides and useful comments during this research. In addition, we thank Vice-President for Research in Science and Research Branch, Tehran. Thanks to the National Iranian Oil Company (NIOC) exploration for continuing support in this project.

\section{References}

[1] Beydoun, Z.R., Hughes Clark, M.W. and Stoneley, R. (1992) Petroleum in the Zagros Basin; a Late Tertiary Foreland Basin Overprinted onto the Outer Edge of a Vast Hydrocarbon-Rich Palaeozoic-Mesozoic Passive Margin Shelf. Vol. 55, American Association of Petroleum Geologists, Memoir, 309-339.

[2] Motiei, H. (1993) Stratigraphy of Zagros. Treatise on the Geology of Iran. Ministry of Mines and Metals, Geological Survey of Iran, Tehran.

[3] Molnar, M. (2006) Tertiary Development of the Zagros Mountains. Geol 418—Earth History. 
[4] Furst, M. (1976) Tektonik und Diapirismus der östlichen Zagrosketten. Zeitschrift der Deutschen Geologischen Gesellschaft, 127, 183-225.

[5] Arian, M. (2013) Physiographic-Tectonic Zoning of Iran’s Sedimentary Basins. Open Journal of Geology, 3, $169-177$. http://dx.doi.org/10.4236/ojg.2013.33020

[6] Blance, E.J.-P. (2003) Structural Styles in the Zagros Simple Folded Zone, Iran. Journal of the Geological Society, 160, 401-412. http://dx.doi.org/10.1144/0016-764902-110

[7] Burberry, C.M., Cosgrove, J.W. and Liu, J.-G. (2008) Spatial Arrangement of Fold Types in the Zagros Simply Folded Belt, Iran. Indicated by Landform Morphology and Drainage Pattern Characteristics. Journal of Maps, 4, 417-430. http://dx.doi.org/10.4113/jom.2008.97

[8] Alavi, M. (2004) Regional Stratigraphy of the Zagros Fold-Thrust Belt of Iran and Its Proforeland Evolution. American Journal of Science, 304, 1-20. http://dx.doi.org/10.2475/ajs.304.1.1

[9] Bahroudi, A. and Koyi, H. (2003) Effect of Ductile and Frictional Décollements on Style of Extension. Journal of Structural Geology, 25, 1401-1423. http://dx.doi.org/10.1016/S0191-8141(02)00201-8

[10] Falcon, N. (1974) Southern Iran: Zagros Mountains. In: Spencer, A., Ed., Mesozoic-Cenozoic Orogenic Belts, Vol. 4, Geological Society of London, Special Publications, 199-211. http://dx.doi.org/10.1144/gsl.sp.2005.004.01.11

[11] Letouzey, J. and Sherkati, S. (2004) Salt Movement, Tectonic Events, and Structural Style in the Central Zagros Fold and Thrust Belt (Iran). 24th Annual Gulf Coast Section SEPM Foundation, Interactions and Bob F. Perkins Research Conference on Salt Sediments Hydrocarbon Prospectivity, Houston, 5-8 December 2004, 535-554.

[12] Sherkati, S. and Letouzey, J. (2004) Variation of Structural Style and Basin Evolution in the Central Zagros (Izeh Zone and Dezful Embayment), Iran. Marine Petroleum Geology, 21, 535-554.

[13] Sherkati. S., Molinaro, M., de Lamotte, D.F. and Lettouzey, J. (2005) Detachment Folding in the Central Eastern Zagros Fold-Belt (Iran): Salt Mobility, Multiple Detachments and Late Basement Control. Journal of Structural Geology, 27, 1680-1696. http://dx.doi.org/10.1016/j.jsg.2005.05.010

[14] Alavi, M. (2007) Structures of the Zagros fold-Thrust Belt in Iran. American Journal of Science, 307, 1064-1095. http://dx.doi.org/10.2475/09.2007.02

[15] Barzegar, F. (1994) Basement Fault Mapping of Zagros Folded Belt (S. W. Iran) Based on Space-Born Remotely Sensed Data. Proceeding of the 10th Thematic Conference on Geologic Remote Sensing: Exploration, Environment and Engineering, San Antonio, 9-12 May 1994, 455-466.

[16] McQuillan, H. (1991) The Role of Basement Tectonics in the Control of Sedimentary Facies, Structural Patterns and Salt Plug Emplacements in the Zagros Fold Belt of Southwest Iran. Journal of Southeast Asian Earth Sciences, 5, 453463. http://dx.doi.org/10.1016/0743-9547(91)90061-2

[17] Talbot, C.J. and Alavi, M. (1996) The Past of a Future Syntaxis across the Zagros. In: Alsop, G.I., Blundell, D.J. and Davison, I., Eds., Salt Tectonics, Vol. 100, Special Publications, Geological Society, London, 89-109. http://dx.doi.org/10.1144/gsl.sp.1996.100.01.08

[18] Setchell, C.M., Cosgrove, J.W. and Liu, J.-G. (2007) The Distribution of Fold Types in the Zagros Simply Folded Belt, Iran. Imperial College, London. (Map Scale 1:100,000)

[19] O’Brien, C.A.E. (1950) Tectonic Problems of the Oil Field Belt of Southwest Iran. Proceedings of 18th International of Geological Congress, Part 6, Great Britain, 45-58.

[20] Jamison, W.R. (1987) Geometric Analysis of Fold Development in Over-Thrust Terrenes. Journal of Structural Geology, 9, 207-219. http://dx.doi.org/10.1016/0191-8141(87)90026-5

[21] Mitra, S. (2002) Fold-Accommodation Faults. AAPG. Bulletin, 86, 671-693.

[22] Mitra, S. (2003) A Unified Kinematic Model for the Evolution of Detachment Folds. Journal of Structural Geology, 25, 1659-1673. http://dx.doi.org/10.1016/S0191-8141(02)00198-0

[23] Suppe, J. (1985) Geometry and Kinematics of Fault-Bend Folding. American Journal of Science, 283, 684-721. http://dx.doi.org/10.2475/ajs.283.7.684

[24] Hessami, K. (2001) The Significance of Strike-Slip Faulting in the Basement of the Zagros Sold and Thrust Belt. Journal of Petroleum Geology, 24, 5-28.

[25] Shamshiri, M. (2001) The Exploration Project of Fars Region. National Iranian Oil Company, Geological Report.

[26] McQuarrie, N. (2004) Crustal Scale Geometry of the Zagros Fold-Thrust Belt, Iran. Journal of Structural Geology, 26, 519-535. http://dx.doi.org/10.1016/j.jsg.2003.08.009

[27] Colman-Sadd, S.P. (1978) Fold Development in Zagros Simply Folded Belt, Southwest Iran. AAPG. Bulletin, 62, 9841003. http://dx.doi.org/10.1306/c1ea4f81-16c9-11d7-8645000102c1865d

[28] Ala, M.A. (1974) Salt Diapirism in Southern Iran. AAPG Bulletin, 58, 1758-1770. 
[29] Kent, P.E. (1970) The Salt of the Persian Gulf Region. Transactions of the Leicester Literary and Philosophical Society, 64, 56-88.

[30] Player, R.A. (1969) The Hormuz Salt Plugs of Southern Iran. MS, PhD Thesis, Reading University, Reading, 300.

[31] Ghanavati, D. (2009) Geometry of Folding Style Analysis in the Coastal Fars and Effects of the Nezamabad Fault in the Structures Region. Ph.D Thesis of Structural Geology, Islamic Azad University, Science and Research Branch of Tehran, Tehran, 200.

[32] Setudehnia, A. and Perry, .J.T. (1965) Geological Map of SE \& SE Fars, Scale 1:250,000. National Iranian Oil Company.

[33] Barzegar, F. (1992) Introducing Firuzabad and the Nezamabad Faults. Proceedings of 10th Geosciences Conference, Geological Survey of Iran, Tehran, 15-16 February 1992.

[34] Furst, M. (1990) Strike-Slip Faults and Diapirism of the South-Eastern Zagros Ranges. Proceeding of Symposium on Diapirism, 2, 149-182.

[35] Nogole-Sadat, M.A.A. and Almasian, M. (1993) Tectonic Map of Iran, Scale 1:1,000,000. Geological Survey of Iran.

[36] Yassaghi, A. (2006) Integration of Landsat Imagery Interpretation and Geomagnetic Data on Verification of DeepSeated transverse Fault Lineaments in SE Zagros. International Journal of Remote Sensing, 27, 1-16. http://dx.doi.org/10.1080/01431160600661283

[37] Twiss, R.J. and Moores, E.M. (1992) Structural Geology. W.H. Freeman and Company, New York, 532.

[38] (2001) Geological Map of Fassa, Iran, Scale: 1:100,000. Geological Survey of Iran.

[39] Ragan, D.M. (1985) Structural Geology, an Introduction to Geometrical Techniques. 3rd Edition, John Wiley \& Sons Inc., Hoboken, 210-215.

[40] Alavi, M. (1994) Tectonics of the Zagros Orogenic Belt of Iran: New Data and Interpretations. Tectonophysics, 229, 211-238. http://dx.doi.org/10.1016/0040-1951(94)90030-2

[41] Letouzey, J. (2005) Detachment Folding in the Central Eastern Zagros fold-Belt (Iran): Salt Mobility, Multiple Detachments and Late Basement Control. Journal of Structural Geology, 27, 1680-1696. http://dx.doi.org/10.1016/j.jsg.2005.05.010

[42] Ramsay, J.G. (1967) Folding and Fracturing of Rocks. McGraw-Hill, New York, 568.

[43] Rickard, M.J.A. (1971) Classification Diagram for Fold Orientation. Geological Magazine, 108, 23-26. http://dx.doi.org/10.1017/S0016756800050925

[44] Maleki, Z., Arian, M., Solgi, A. and Ganjavian, MA. (2014) The Elements of Fold Style Analysis in the Khaftar Anticline, Zagros, Iran. Open Journal of Geology, 4, 79-92.

[45] Maleki, Z., Arian, M., Solgi, A. and Ganjavian, MA. (2013) Sediment Deformations on Strike Slip Fault Blocks and Analogue Modeling: A Case Study of the Nezamabad Fault, Interior Fars, Zagros. Journal of Sciences (Islamic Azad University), 89, 39-51. (In Persian)

[46] Maleki, Z., Arian, M., Solgi, A. and Ganjavian, MA. (2015) Analysis Elements of Fold Style in the Karbasi Anticline, Interior Fars Region, Zagros. Geosciences, 24, 293-302. 